\title{
Gender, Wealth, and Participation in Community Groups in Meru Central District, Kenya
}

\author{
Kristin E. Davis and Martha Negash \\ International Food Policy Research Institute
}

International Research Workshop on 'Gender and Collective Action' October 17-21, 2005・Chiang Mai, Thailand

The CGIAR Systemwide Program on Collective Action and Property Rights (CAPRi) is an initiative of the 15 centers that belong to the Consultative Group on International Agricultural Research. The initiative promotes comparative research on the role played by property rights and collective action institutions in shaping the efficiency, sustainability, and equity of natural resource systems. CAPRi's Secretariat is hosted by the International Food Policy Research Institute's (IFPRI) Environment and Production Technology Division (www.ifpri.org).

CAPRi Working Papers contain preliminary material and research results and are circulated prior to a full peer review in order to stimulate discussion and critical comment. It is expected that most Working Papers will eventually be published in some other form, and that their content may also be revised. http://dx.doi.org/10.2499/CAPRiWP65.

Copyright $\odot$ May 14, 2007 International Food Policy Research Institute. All rights reserved. Sections of this material may be reproduced for personal and not-for-profit use without the express written permission of but with acknowledgment to IFPRI. To reproduce the material contained herein for profit or commercial use requires express written permission. To obtain permission to reprint, contact the IFPRI Communications Division at ifpri-copyright@cgiar.org.

CGIAR Systemwide Program on Collective Action and Property Rights (CAPRi) c/o INTERNATIONAL FOOD POLICY RESEARCH INSTITUTE 


\section{ACKNOWLEDGEMENTS}

The authors gratefully acknowledge the support of USAID for funding for the study, and the helpful comments and suggestions of several anonymous reviewers. 


\begin{abstract}
A mixed-methods, multiple-stage approach was used to obtain data on how gender and wealth affected participation in community groups in Meru, Kenya, and how men and women farmers obtain and diffuse agricultural information. Research techniques included participant observation, documentary analysis, semi-structured interviews, social mapping, group timelines, and structured questionnaires. Dairy-goat farmer groups were interviewed for the study. Qualitative data provided baseline information, and helped in the formulation of research questions. Quantitative data were analyzed using contingency tables, descriptive statistics, correlations, tests of significance, and regression. Factors that affected participation in different types of groups included household composition, age, and gender. Women made up 59 percent of the dairy-goat group (DGG) members, with the DGG project encouraging women's participation. Women made up 76 percent of DGG treasurer positions; 43 percent of secretary positions, and 30 percent of chairperson positions. Gender also influenced participation in clan groups, water groups, and merry-go-round (savings and loans) groups. Wealth did not appear to have a significant effect on participation in community groups. Extension was the most important information source for both men and women farmers. However, church and indigenous knowledge (passed on from parents) seemed more important to women. Both men and women mentioned other farmers, groups, and "baraza" (public meetings used to make announcements and diffuse information) as important information sources, but they rated them at different levels of importance. Men were diffusing information to greater numbers of people than women, although men and women diffused to similar sources. This study shows that because men and women traditionally participate in different types of groups and receive agricultural information from different sources, development agencies must target different types of groups and institutions to reach men, women, or poor farmers. Mechanisms should be developed to include women, the poor, and other targeted groups in community associations that provide market and other income-earning opportunities.
\end{abstract}

Keywords: Gender, wealth, community and farmer groups, extension, Kenya 


\section{TABLE OF CONTENTS}

Introduction $\quad 1$

$\begin{array}{ll}\text { Background } & 4\end{array}$

$\begin{array}{ll}\text { Methods } & 6\end{array}$

$\begin{array}{ll}\text { Results } & 10\end{array}$

$\begin{array}{ll}\text { Discussion } & 23\end{array}$

$\begin{array}{ll}\text { Conclusions } & 27\end{array}$

References $\quad 29$ 


\title{
Gender, Wealth, and Participation in Community Groups in Meru Central District, Kenya
}

\author{
Kristin E. Davis ${ }^{1}$ and Martha Negash ${ }^{2}$
}

\section{INTRODUCTION}

Social capital in the form of groups is used in communities worldwide, especially in rural areas, as safety nets to cope with risks and for mutual assistance. Groups provide a means of collective action for farmers, providing resources such as credit, labor, and information. Groups allow farmers to obtain new technologies, benefit from economies of scale, enter into stable relationships with suppliers, and set rules for natural resource management (Place et al. 2002; Stringfellow et al. 1997). They are also beneficial for social and spiritual reasons.

There are many types of groups in rural Kenya. They are part of the social fabric of the country. Although groups have been a type of social capital used by farmers for generations in Africa, the harambee movement following Kenyan independence greatly increased the number of grassroots-level groups with development objectives. Harambee, meaning "let's all work together," was a government initiative designed to encourage people to contribute resources to supplement and complement the government's development efforts. Many self-help groups were formed as a result. Today, registration of groups with the government is usually required for farmers to receive government or other project assistance.

\footnotetext{
${ }^{1}$ Research Fellow, International Food Policy Research Institute, ISNAR Division, Addis Ababa, Ethiopia, k.davis@,cgiar.org

${ }^{2}$ Research Officer, International Food Policy Research Institute, ISNAR Division, Addis Ababa, Ethiopia, m.negash@,cgiar.org
} 
Although farmer groups are ubiquitous in rural Kenya and much of the developing world, there is little empirical evidence on participation in community groups. Do all farmers participate equally in community groups? Are groups accessible to the poor? Are there gender differences as to participation in farmer groups or in leadership positions of the groups? Are there differences between men and women's information sources and to whom they disseminate information? These issues are important if we are to include often marginalized groups of farmers such as women and the poor in the development process, and to use groups as a vehicle for dissemination of information and technologies.

Several studies have looked at participation in community groups and other types of social capital. In the Philippines, Godquin and Quisumbing (2006) found that asset-rich, better educated, closer-to-town households were more likely to participate in groups and have larger social and economic assistance networks. Although there was not a significant difference in the number of groups in which men and women participated, the type of groups was significantly different between men and women. Men tended to join burial and production groups, while women were more likely to participate in civic groups.

In Uganda, Katungi et al. (2006) found that social capital is very important for information exchange. Social capital was measured in terms of belonging to associations, civic engagement (reading a newspaper, listening to radio, etc), and attending social institutions such as weddings and marketplaces. They showed that male-headed households have better access to social capital, and tended to use civic engagement and social institutions more than femaleheaded households. While male-headed households had larger social networks, there were no differences between male- and female-headed households as to "weak ties"- the relatives and friends from their social networks outside the sub-county. Female-headed households engaged 
less often in information exchange. Finally, the researchers showed that men and women had an equal propensity to join groups, and thus groups should be used for information diffusion.

Place et al. (2002) examined the performance of rural groups in Kenya. They presented empirical evidence regarding various hypothesized explanatory factors for relative group performance levels. They found that groups are very diverse and dynamic, taking on new projects and abandoning others. They also found that women tended to join groups in order to purchase household items or for social insurance, while men often joined to gain market access or as a coping mechanism. In a follow-up paper, Kariuki and Place (2005) found that men and women engage in similar activities but for different reasons. The extent of participation is also different for men and women.

Finally, in India, Agrawal et al. (2006) looked at participation in forest management, and found that active participation by women led to positive outcomes in terms of regulating grazing and felling.

The purpose of this study was to examine the effects of gender and wealth on participation in community groups in Meru, Kenya, and to see whether differences exist in information access and diffusion by men and women farmers. For this study, we examined membership in various community-level groups: self-help, savings and loans, labor sharing, religious, etc. Cooperatives are not included. The following research questions were addressed:

- Are there differences in men and women's participation in dairy-goat groups (DGGs) or other types of community groups?

- Are there differences in participation by wealth level in DGGs or other types of groups?

- What differences, if any, are there between men and women's sources of information for agriculture, and the ways in which they diffuse them? 


\section{BACKGROUND}

Meru Central District is an important smallholder agriculture district in Kenya's Eastern Province, covering 2,982 square kilometers (Meru Central District Development Plan 2002). It lies between $0^{\circ} 3$ ' $45^{\prime \prime}$ North and $0^{\circ} 2^{\prime} 30^{\prime \prime}$ South and between $37^{\circ}$ and $38^{\circ}$ East. Administratively, within the district there are 10 divisions, 27 locations, and 75 sublocations. Meru Central is bordered by Mount Kenya on the west and drier lowlands to the north and east. It ranges in altitude from 300 to $5199 \mathrm{~m}$ at the peak of Mt. Kenya. It has nearly all of the agroecological zones of Kenya (Teel 1985; Were and Wandibba 1988).

Rainfall is bimodal, falling between March and June (long rains) and October through December (short rains). The southeastern slopes of Mount Kenya, where many of the farms lie, receive between 1250 and $2500 \mathrm{~mm}$ of rainfall per year (Meru Central District Development Plan 2002). The leeward side of the mountain and northern and eastern lowlands receive between $380 \mathrm{~mm}$ and $1000 \mathrm{~mm}$ annually.

Population within the district is 521,518 . The growth rate is 1.48 percent (Meru Central District Development Plan 2002). Population density is an average of 167 people per square mile. Farm size averages 1.1 hectares for smallholders. Although people are moving to urban areas, absolute numbers of farmers in the rural areas are growing, putting pressure on the natural resources of the district. Over 45 percent of the population is classified as poor (Meru Central District Development Plan 2002).

The Meru Dairy-goat and Animal Healthcare Project started working in the greater Meru area in 1996, targeting the poorest farmers in medium- and low-agricultural potential zones, by working with over 80 self-help dairy-goat groups in two districts, Meru Central and Meru South (this study only covered Meru Central). The purpose of the project was to "improve the 
productivity of local goats through better management and access to sustainable healthcare and genetic improvement, and of local dairy cattle through better access to sustainable healthcare systems" (FARM-Africa 2002: 8).

Activities of the project included:

- Community-based breeding of local goats with Toggenburg dairy-goats;

- Formation and training of autonomous self-help groups to undertake breeding activities;

- Development of community animal health care workers and a privatized veterinary and drug supply service;

- Improvement of fodder supplies through community bulking and on-farm planting of suitable fodder; and

- Development of an effective extension support service through the existing Ministry staff (agriculture and livestock ministries) and extension system.

The project worked through both the existing public extension service and the private sector to support small-scale farmers in the district. Through these linkages, the project helped the dairy-goat groups obtain loans, training, and improved bucks for breeding. The project is estimated to have benefited the welfare and income of 20,000 families in the area in both districts. Descriptive data for individual project and non-project farmers interviewed are shown in Table 1. 
Table 1--Descriptive data for individuals interviewed $(n=88)$

\begin{tabular}{|c|c|c|c|}
\hline Variable & Sublevel & $f$ & $\%$ \\
\hline \multirow[t]{3}{*}{ Administrative location } & Abothoguchi Central & 25 & 28 \\
\hline & Abothoguchi East & 24 & 27 \\
\hline & Miriga Mieru East & 39 & 44 \\
\hline \multirow[t]{3}{*}{ Age } & $<30$ years & 10 & 11 \\
\hline & $30-50$ years & 38 & 43 \\
\hline & $>50$ years & 40 & 46 \\
\hline \multirow[t]{4}{*}{ Housing } & Tin roof and cement block walls & 14 & 16 \\
\hline & Tin roof and timber walls & 53 & 62 \\
\hline & Tin roof and mud walls & 16 & 19 \\
\hline & Thatch roof and timber walls & 2 & 2 \\
\hline \multirow{4}{*}{ Water source } & Piped & 44 & 50 \\
\hline & Borehole/well & 8 & 9 \\
\hline & Stream/river & 32 & 36 \\
\hline & Other & 4 & 5 \\
\hline \multirow[t]{4}{*}{ Type of household } & Married couple & 65 & 74 \\
\hline & Men, single & 2 & 2 \\
\hline & Women, husband away & 10 & 11 \\
\hline & Women, single & 11 & 13 \\
\hline \multirow[t]{3}{*}{ Wealth level of respondents ${ }^{a}$} & Below average & 25 & 28 \\
\hline & Average & 48 & 55 \\
\hline & Above average & 15 & 17 \\
\hline \multirow{4}{*}{ Other information } & Receive remittances & 46 & 52 \\
\hline & Own title deed to household land & 47 & 54 \\
\hline & Maize is most important food crop & 67 & 76 \\
\hline & Member of MGBA ${ }^{\mathrm{b}}$ & 23 & 26 \\
\hline
\end{tabular}

${ }^{\mathrm{a}}$ Wealth level was judged by expert opinion and was based upon the land size related to the agroecological zone, type of housing, household composition, and number of animals.

' Meru Goat Breeders' Association

\section{METHODS}

A mixed-methods, multiple-stage approach was used to obtain data. The ten-month study consisted of a preliminary phase, survey research, and a follow-up stage that included a workshop to obtain stakeholder feedback (farmers, government officials and project staff attended), and took place in 2003-2004. The approach used obtained both qualitative and quantitative information to answer research questions. 
The population of interest to the study was small-scale farmers in Meru Central District in Kenya (those with landholdings generally between 0.25 and 1.5 hectares). The target population was (1) those farmers who were involved in dairy-goat groups through a joint project of the Ministry of Livestock and Fisheries Development and the non-governmental organization (NGO) FARM-Africa, and (2) community members not involved in the DGGs who had received information or technologies from the DGGs.

From that population of small-scale farmers, a sampling frame of farmers on project lists was put together. From the sampling frame, random samples of individual households were drawn from the lists to elicit data for the study. Individual members of dairy-goat groups $(\mathrm{n}=43$; women $=24$ and men $=19$ ) were chosen at random from group lists. Also of interest to the study were farmers who have benefited from the group (through group dissemination of information or technology $)$. These non-dairy-goat group individuals $(n=45 ;$ women $=22$ and men $=23)$ were sampled by asking the farmer groups for lists of people who had benefited from their group, and then randomly selecting farmers from that list. Units of analysis thus included both individual farmers (dairy-goat members and non-members) and the dairy-goat groups. All existing project dairy-goat groups in the district were interviewed $(n=46)$. Purposive sampling was used for key informant interviews $(n=24$; women $=7$ and $\operatorname{men}=17)$.

Topic guides were used for semi-structured interviews with key informants, which included general questions with probes. More formal questionnaires for both individual farmers and farmer groups were then developed based on this information, from other questionnaires used in similar research, and from document analysis. 
Validity of the formal survey was ensured by having a panel of experts examine the instrument of data collection, pilot testing the instrument, assuring respondents of anonymity, training of translators, and using member checks. The researcher used local languages and indigenous categories to ensure common understanding among respondents. The findings were discussed with participants at the end of the study for further validation.

There were two types of dairy-goat groups in the project, both of whom engaged in the same types of activities, but with slightly different support (Table 2). The NGO FARM-Africa helped to start 20 dairy-goat groups in Meru Central District, based upon local participatory poverty measures of the community. Criteria for poverty included an inability to send children to school, lack of regular income, temporary housing, having no cattle, and small land size relative to the area. Those classified as poor were allowed to join the groups. These project-supported groups were known as "FARM" groups. However, many other farmers in the district decided to start their own DGG groups, albeit without formal FARM-Africa support. These were known as “extension” groups. They bought their own breeding buck (while FARM groups were given one), and were trained by extension staff or other dairy-goat groups without the typical project support. There were 26 extension groups. Both extension staff and FARM-Africa were involved with all of the groups, but the project supported the FARM groups to a higher degree. 


\section{Table 2--Types of dairy-goat groups in Meru Central District}

\begin{tabular}{|c|c|c|c|}
\hline & & FARM Groups $(n=20)$ & Extension Groups $(\mathrm{n}=26)$ \\
\hline \multirow[t]{4}{*}{ Description } & & Formally part of project & Informally part of project \\
\hline & & $\begin{array}{l}\text { Formed based on poverty } \\
\text { measures }\end{array}$ & $\begin{array}{l}\text { Formed based on members' } \\
\text { choices }\end{array}$ \\
\hline & & Given a breeding buck & Purchased a breeding buck \\
\hline & & $\begin{array}{l}\text { Had full support and } \\
\text { training from project }\end{array}$ & $\begin{array}{l}\text { Had training from either } \\
\text { project or other DGGs }\end{array}$ \\
\hline $\begin{array}{l}\text { Mean no. of members } \\
\text { (standard deviation) }\end{array}$ & & $21.30(6.07)$ & $24.62(10.02)$ \\
\hline \multirow{4}{*}{$\begin{array}{l}\text { Main objectives of the group } \\
\text { (by frequency) }\end{array}$} & DGG & 20 & 24 \\
\hline & $\begin{array}{l}\text { Income } \\
\text { generation }\end{array}$ & 2 & 5 \\
\hline & $\begin{array}{l}\text { Merry-go- } \\
\text { round }\end{array}$ & 9 & 15 \\
\hline & Other & 9 & 14 \\
\hline
\end{tabular}

For the group interviews in this study, typically four to six farmers from one dairy-goat group were interviewed as a group over approximately a two-hour period. Groups were asked to send both leaders and regular group members; men and women farmers (three of each if possible); and both wealthier and less wealthy farmers. The group questionnaire consisted of 66 questions and participatory activities (group timelines and Venn diagrams). Group timelines were used to understand how groups had evolved due to Place et al.'s (2002) findings that age of group and changes in purpose over time affect group success. Venn diagrams were used to show group linkages. $^{3}$

\footnotetext{
${ }^{3}$ These results are beyond the scope of this paper and can be found in Davis (2004).
} 
Following the group interviews, randomly-selected DGG individual group members (both FARM and extension groups) were sought to both corroborate the group information and to obtain information at the household level. One group member and one non-member who had benefited in some way from the group were sought at each interview site. Researchers strived to have a balance of men and women respondents. The DGG member or the non-member who had benefited was interviewed irrespective of whether they were the household head (although this information was included in the survey—see Table 1). Data on household type such as male- or female-headed were included in the analysis. However, type of household was not a significant factor in membership in groups. The individual questionnaire consisted of 48 questions, and took between 30 to 60 minutes to complete.

Quantitative data from the questionnaires were entered and analyzed using the Statistical Package for Social Sciences (SPSS) software. The results are presented mainly using descriptive analyses. Measures of independence and association such as the chi-square statistic and the gamma measure ( $\gamma$, for ordinal data), and multiple linear regression were used to examine and predict relationships among the study variables.

\section{RESULTS}

\section{Factors Affecting Participation in Community Groups ${ }^{4}$}

It is quite common for farmers in Meru Central district to be a member of some type of group (98 percent of the individuals interviewed were group members of one kind or another). In addition to women's and men's farmer groups, others included youth, sports, church, school,

\footnotetext{
${ }^{4}$ Findings presented in this section are drawn from Davis (2004).
} 
cattle dip, political party, water, utensils, merry-go-rounds, clan, funeral, and marketing groups. Groups provided an important avenue for obtaining information and technologies, as well as moral support. Individual farmers $(n=88$; women $=46$; men $=42)$ were in an average of 2.3 groups each, with the majority being in one or two groups. Men were in an average of 2.33 groups, and women an average of 2.28. Ninety-seven percent of the farmers in the dairy-goat groups were members of other types of groups. The main groups that individual farmers in the study belonged to were dairy-goat, church, clan, merry-go-round, water, and women's groups (Table 3).

Table 3--Percent of individual farmers belonging to each group type by gender $(\mathbf{n}=\mathbf{8 8})$

\begin{tabular}{|c|c|c|c|c|c|c|c|c|}
\hline \multirow[b]{2}{*}{ Groups } & \multicolumn{2}{|c|}{ Women $(n=46)$} & \multicolumn{2}{|c|}{$\operatorname{Men}(n=42)$} & \multicolumn{2}{|c|}{ Total $(n=88)$} & \multirow[b]{2}{*}{$\chi^{2}$} & \multirow[b]{2}{*}{$p$} \\
\hline & $f$ & $\%$ & $f$ & $\%$ & $f$ & $\%$ & & \\
\hline Dairy-goat group & 24 & 52 & 20 & 48 & 44 & 50 & 0.18 & 0.67 \\
\hline Church & 21 & 46 & 18 & 43 & 39 & 44 & 0.69 & 0.79 \\
\hline Merry-go-round & 16 & 35 & 2 & 5 & 18 & 21 & 12.02 & $0.00 *$ \\
\hline Women & 14 & 30 & 0 & 0 & 14 & 16 & 15.03 & $0.00 *$ \\
\hline Clan & 7 & 15 & 16 & 38 & 23 & 26 & 5.89 & $0.02 *$ \\
\hline Water group & 4 & 9 & 14 & 33 & 18 & 21 & 8.09 & $0.00 *$ \\
\hline Farm group $^{\mathrm{a}}$ & 1 & 2 & 5 & 12 & 6 & 7 & 3.24 & $0.07 * *$ \\
\hline Village group $^{a}$ & 0 & 0 & 3 & 7 & 3 & 3 & 3.36 & $0.07 * *$ \\
\hline
\end{tabular}

*the variable is statistically dependent of the categorical variable (gender) at $99 \%$ and ** at $95 \%$

${ }^{a}$ Kruskal-Wallis nonparametric procedure for small samples used

Although the study was looking particularly at dairy-goat groups, data were also collected on other types of groups of which farmers were members (see Table 3). The chi-square test $(\chi 2)$ shows that membership in groups is in many cases associated with gender. Women tended to belong to merry-go-round and women's groups, while men tended to belong to clan, water, farm, and village groups. Clan group members also tended to be members of water groups. Membership in church groups did not appear to be related to gender or respondent 
wealth level; however, members of church groups also were more likely to be members of merry-go-rounds.

Another factor affecting membership in groups was household composition, which is partly connected to both wealth and gender. Household composition here is the ratio of producers to consumers and numbers of men, women, boys, and girls within the household. ${ }^{5}$ Certain households were more stressed with regard to labor available (producers) relative to the number of mouths to feed (consumers). This factor appeared to affect membership in church groups, women's groups, and clan groups.

\section{Church groups}

Church group members tended to be in a lower age bracket than non-members. Being a member of a merry-go-round group increased the odds of being a church group member. As the number of girls under the age of 10 and the age of the respondent decreased, the odds of church group membership increased. The producer to consumer ratio was significantly larger for church group members; in other words, they had a higher number of producers and lower number of consumers than non-members.

\section{Clan groups}

Clan group members tended to be men. They also had more boys under the age of 10 with results approaching significance. Being a member of a water group increased the odds of being in a clan group. They received fewer remittances (off-farm income) than did nonmembers, although not at a statistically significant level. Clan group members thus likely had fewer resources in terms of remittances, and greater household stress in terms of labor availability than non-members.

\footnotetext{
${ }^{5}$ For the purposes of this study, "consumers" are defined as all people in the household who eat and sleep on the farm, while "producers" refers to all those between the ages of 11 and 50. This age range is used because people in it can contribute significantly to labor on the farm.
} 


\section{Merry-go-rounds}

Merry-go-round members had smaller land sizes and tended to be of lesser age, with results that approached significance. Members also tended to be women. Being a member of a church group and a women's group both increased the odds of being a member of a merry-goround. Merry-go-round members were thus likely to be women community members with fewer resources who were in multiple groups.

\section{Water groups}

Water group members were likely to be men. They were more educated than nonmembers with results that approached significance (7.72 years for members; 6.41 for nonmembers). Having a title deed increased the odds of being a member of a water group, as did being a member of a clan group. It appears that the overall wealth rating of respondents was associated with belonging to water groups. (Enumerators gave wealth ratings based on various factors such as household composition, housing type, size of land, crops grown and number of livestock.) Water group members thus appeared to be men who were wealthier than nonmembers.

\section{Women's groups}

Women's group members had significantly fewer children under the age of 10. Odds of being a member of a women's group increased with increased levels of producers, and with being a member of a church group. Age, total number of children under 10, and a high producer to consumer ratio decreased the odds of being in women's groups. Of course, significantly more members were women. Women's group members appeared to be people in the community who had low producer to consumer ratios, were women, and were church group members. 
These results seem to point to the fact that household composition, wealth, and participation in other types of groups, among other factors, affects participation in certain groups. For more information on participation in these non-DGGs see Davis (2004).

Respondents were asked about their reasons for joining the dairy-goat group, or their most important group if they were not in a DGG (either FARM or extension DGGs). As shown in Table 4, the main reasons for joining groups were to increase income and gain tangible benefits, such as access to improved breeds of goats, or to money through structures like merrygo-rounds. Fellowship was also another important reason to join groups. Eleven percent of women and 10 percent of men who were in groups said they joined the group that was most important to them for fellowship reasons (they could have more than one reason for joining groups)). One of the DGGs met twice a week just for fellowship (rather than for technical reasons).

Table 4--Reasons why individual farmers join groups by gender

\begin{tabular}{|c|c|c|c|c|}
\hline & \multicolumn{2}{|c|}{ Women $(n=46)$} & \multicolumn{2}{|c|}{$\operatorname{Men}(n=42)$} \\
\hline & $f$ & $\%$ & $f$ & $\%$ \\
\hline Tangible benefits e.g. access to improved breeds of goats or money & 28 & 62 & 21 & 51 \\
\hline Other & 6 & 13 & 1 & 2 \\
\hline Fellowship & 5 & 11 & 4 & 10 \\
\hline Increase income & 4 & 9 & 7 & 17 \\
\hline Emergency & 1 & 2 & 4 & 10 \\
\hline Services & 1 & 2 & 2 & 5 \\
\hline Market & 0 & 0 & 1 & 2 \\
\hline Labor & 0 & 0 & 1 & 2 \\
\hline Total & 45 & 100 & 41 & 100 \\
\hline
\end{tabular}

Note: $\chi^{2}(7, \mathrm{n}=88)=9.47 ; p<.22$ 


\section{Factors Affecting Participation in Dairy-goat Groups}

We now look specifically at DGGs, for which we have more data than the other types of community groups examined above. However, it should be noted that the project was targeting both the poor and women for inclusions, and results should be viewed with this in mind. In other words, the targeting of women and the poor may have led to higher numbers of these groups than would "normally" be seen.

Ninety-six percent of dairy-goat groups were of mixed gender, with two groups being only one gender (one all women and one all men). Overall, 59 percent of the DGG members (FARM and extension) were women. As mentioned earlier, the project encouraged women to take part in the groups and in group leadership. The all-men group was an extension group, while the all-women group was a FARM group. Gender did not significantly affect group success (for more details on factors affecting group success see Davis 2004 and Davis et al. 2004). Nine of the dairy-goat groups (both FARM and extension) had 80 percent or greater women membership. There were also many women in leadership positions in all of the dairy-goat groups; 30 percent of the groups had women chairpersons, 43 percent had women secretaries and 76 percent had women treasurers. The household characteristics of DGG members (FARM and extension) are shown in Table 5. Types of households are shown in Table 1.

There appears to be a difference in education level between the two gender groups. Out of the 24 women dairy-goat members 42 percent were below or equal to standard four, while only 15 percent of men are in this category (Table 5). This could also be because educated women participated in other activities than the dairy-goat groups. Because the project was targeting poor farmers, and also encouraging participation by women, this may be a result of targeting the poorer women who also have less education. 
Table 5--Household characteristics of all dairy-goat group members by gender

\begin{tabular}{|c|c|c|c|c|c|}
\hline \multirow[t]{2}{*}{ Variable } & \multirow[t]{2}{*}{ Sub-level } & \multicolumn{2}{|c|}{ Women } & \multicolumn{2}{|c|}{ Men } \\
\hline & & $f$ & $\%$ & $f$ & $\%$ \\
\hline \multirow[t]{3}{*}{ Age } & $<30$ years & 1 & 4 & 2 & 10 \\
\hline & $31-49$ years & 15 & 63 & 5 & 25 \\
\hline & $>50$ years & 8 & 33 & 13 & 65 \\
\hline \multirow[t]{3}{*}{ Wealth level of respondents ${ }^{\mathrm{a}}$} & Below average & 6 & 2 & 6 & 30 \\
\hline & Average & 14 & 58 & 13 & 65 \\
\hline & Above average & 4 & 17 & 1 & 5 \\
\hline \multirow[t]{2}{*}{ Receive remittances } & No & 13 & 54 & 10 & 50 \\
\hline & Yes & 11 & 46 & 10 & 50 \\
\hline \multirow[t]{4}{*}{ Water source } & Piped & 10 & 42 & 9 & 45 \\
\hline & Borehole/well & 3 & 13 & 2 & 10 \\
\hline & Stream/river & 10 & 42 & 9 & 45 \\
\hline & Other & 1 & 4 & 0 & 0 \\
\hline \multirow[t]{3}{*}{ Education level } & Less or equal to standard 4 & 10 & 42 & 3 & 15 \\
\hline & Between standards 5 and 8 & 8 & 33 & 13 & 65 \\
\hline & Form 1 and above & 6 & 25 & 4 & 20 \\
\hline \multirow[t]{4}{*}{ Construction of house } & Permanent roof walls & 4 & 17 & 1 & 5 \\
\hline & Permanent roof timber walls & 13 & 54 & 14 & 70 \\
\hline & Permanent roof mud walls & 6 & 25 & 4 & 20 \\
\hline & Thatch roof mud walls & 1 & 4 & 1 & 5 \\
\hline \multirow[t]{2}{*}{ Member of MGBA } & No & 11 & 48 & 9 & 45 \\
\hline & Yes & 12 & 52 & 11 & 55 \\
\hline
\end{tabular}

${ }^{\mathrm{a}}$ Wealth level was judged by expert opinion and was based upon the land size related to the agroecological zone, type of housing, household composition, and number of animals.

Members of the DGGs do not seem to be more or less wealthy than non-members (see Table 6). According to project documents and various informants, the DGG project was designed to target poorer farmers in the communities. However, there were no significant differences between dairy-goat group members and neighboring non-members with regard to wealth rating by outside enumerators $(\chi 2(2, n=88)=0.46 ; \mathrm{p}<.29)$, number of livestock, or other factors that contribute to wealth level such as size of land, years of education, and remittances. Type of 
housing $\left(\chi^{2}(4, \mathrm{n}=88)=4.67 ; \mathrm{p}<.32\right)$ and source of water $\left(\chi^{2}(3, \mathrm{n}=88)=3.44 ; \mathrm{p}<.33\right)$ were not significantly different for members and non-members either.

Group means between DGG and non-members are compared in Table 8. We break down the household into different age and gender groups because of the influence these have on the producer to consumer ratio within the household.

Table 6--Frequencies of wealth indicators of dairy-goat and non-group members $(\mathbf{n}=\mathbf{8 8})$

\begin{tabular}{lllll}
\hline Indicator & Sublevel & DGG member & Non-member & $\begin{array}{l}\text { Total } \\
\text { no. }\end{array}$ \\
\hline Wealth level of $_{\text {respondents }}{ }^{\mathrm{a}}$ & Below average & $12(14)$ & $13(15)$ & $25(28)$ \\
& Average & $27(31)$ & $21(24)$ & $48(55)$ \\
& Above average & $5(6)$ & $10(11)$ & $15(17)$ \\
\hline House type & Permanent roof/stone walls & $5(6)$ & $9(10)$ & $14(16)$ \\
& Permanent roof/timber walls & $27(31)$ & $27(31)$ & $54(61)$ \\
& Permanent roof and mud walls & $10(11)$ & $7(8)$ & $17(19)$ \\
& Thatch roof and mud walls & $0(0)$ & $2(2)$ & $2(2)$ \\
& Other & $0(0)$ & $1(1)$ & $1(1)$ \\
\hline Water source & Piped & $19(22)$ & $25(28)$ & $44(50)$ \\
& Borehole/well & $5(6)$ & $3(3)$ & $8(9)$ \\
& Stream/river & $1(1)$ & $3(3)$ & $4(5)$ \\
\hline
\end{tabular}

${ }^{a}$ Wealth level was judged by an outsider rater and was based upon the land size related to the agroecological zone, type of housing, household composition, and number of animals. Note: $\gamma=-0.104 ; \mathrm{p}<.541$ for wealth level Note: Figures in ( ) are percentages

As seen in Table 7, there were significant differences between members and non-members of dairy-goat groups with regard to the number of men and total children under the age of 10, total number of household members, and total number of consumers. This shows that individuals with more children under the age of 10 , more consumers and larger households are more likely to be members of dairy-goat groups. Basically, the DGG members had larger and likely more labor-stressed households.

Multivariate analysis was used to further analyze the factors affecting participation in the DGGs (both FARM and extension). For this analysis, various factors were regressed upon the dependent variable "group membership" in a binary logistic model. The generic terms for the 
two possible outcomes are success and failure, and the "odds" equal the probability of success divided by the probability of failure. The odds of a particular outcome is obtained by the ratio $\pi$ $/(1-\pi)$. The log of the odds is called the logistic transformation or logit. The logistic regression model is logit $(\pi)=\alpha+\beta X$ (Agresti and Finlay 1997). As the outcome (in this case, participation in a DGG) increases from 0 to 1 , the odds increase from 0 to infinity. This model tests the probability that the independent variable $\mathrm{X}$ has no effect on the dependent variable $\mathrm{Y}$ (Agresti and Finlay 1997).

Table 7--Factors affecting participation in all dairy-goat groups $(\mathbf{n}=\mathbf{8 8})$

\begin{tabular}{|c|c|c|c|c|c|c|}
\hline Response & Mem & $=44)$ & Non- & ember & $=44)$ & \\
\hline & $\underline{M}$ & SD & $\mathrm{M}$ & SD & $t$ & $p$ \\
\hline No. girls under 10 years & $\overline{0.68}$ & $\overline{0.88}$ & $\overline{0.48}$ & $\overline{0.70}$ & $\overline{1} .21$ & 0.23 \\
\hline No. boys under 10 & 0.75 & 0.94 & 0.39 & 0.72 & 2.03 & $0.05^{* *}$ \\
\hline Total household members & 5.41 & 1.63 & 4.39 & 1.96 & 2.66 & $0.01 * *$ \\
\hline Total children $\leq 10$ years & 1.43 & 1.30 & 0.86 & 0.93 & 2.36 & $0.02 * *$ \\
\hline Total number of consumers on-farm & 5.55 & 1.84 & 4.39 & 1.94 & 2.88 & $0.01 * *$ \\
\hline Total number producers on-farm & 3.43 & 1.82 & 2.80 & 1.64 & 1.72 & $0.09 *$ \\
\hline No. of groups farmer belongs to & 2.59 & 1.04 & 2.02 & 1.68 & 1.91 & $0.06^{*}$ \\
\hline Education of respondent (total years) & 6.65 & 3.66 & 6.71 & 3.48 & -0.08 & 0.94 \\
\hline Land size of respondent (acres) & 4.66 & 3.59 & 4.19 & 4.02 & 0.58 & 0.56 \\
\hline Type of housing ${ }^{\mathrm{a}}$ & 3.75 & 0.84 & 3.95 & 0.86 & -1.13 & 0.26 \\
\hline Water source ${ }^{b}$ & 1.95 & 0.99 & 2.14 & 1.07 & -0.83 & 0.41 \\
\hline
\end{tabular}

The binary regression model was built by running the various factors against the outcome (participation in DGG groups). The backward method of model-building was used, which starts with all of the variables and then removes them one by one if they do not significantly contribute to the equation (George and Mallery 2001). Because the model chooses the best possible explanatory variables, the model drops from the equation those factors that do not significantly 
affect the outcome. Using model building with the Wald statistic ${ }^{6}$, the researchers could examine which factors most significantly contributed to participation in the various groups. The regression model for dairy-goat group membership is shown in Table 8 .

Table 8--Binary logistic regression analysis showing factors associated with membership in dairy-goat groups $(n=44)$

\begin{tabular}{lcccccc}
\hline & B & SE & Wald & df & $p$ & Exp (B) \\
\hline Constant & -0.56 & & & & & \\
Total no. of consumers & 0.28 & 0.13 & 4.86 & 1 & $0.03^{* *}$ & 1.32 \\
No. of groups farmer is in & 0.47 & 0.23 & 5.52 & 1 & $0.03^{* *}$ & 1.61 \\
Church group member $^{\mathrm{a}}$ & 1.15 & 0.53 & 4.50 & 1 & $0.03^{* *}$ & 3.14 \\
\hline
\end{tabular}

${ }^{\mathrm{a}} 0=\mathrm{No} ; 1=$ Yes

**Significant at the .05 level

Note: $\left(\chi^{2}\right.$ for model $\left.=15.53 ; \mathrm{df}=3 ; p<.00\right)$

This binary logistic model is interpreted as follows. As with linear regression models, positive numbers mean that the probability of being a member of a dairy-goat group increases with higher levels of consumers, with higher numbers of groups that the farmers are in, and with membership in a church group. These data show that the dairy-goat group members had a higher ratio of consumers to producers, and thus more dependents. Thus they likely had higher labor and time constraints to deal with than DGG non-members.

Furthermore, the model can be interpreted looking at the effect of $\mathrm{e}^{\beta}$ on the odds. Every unit increase in $\mathrm{X}$ leads to a multiplicative effect of $\mathrm{e}^{\beta}$ on the odds. For instance, for number of consumers, $\mathrm{e}^{\beta}=\mathrm{e}^{.28}$ which equals 1.32 . This means that when the total number of consumers increases by one unit, the odds of being a dairy-goat group member increase by 1.32 .

In Table 8, the wealth ranking of the individual and gender were variables that dropped out of the regression equation. This was because they did not contribute significantly to the equation, while the number of consumers, the number of groups the individual was in, and

\footnotetext{
${ }^{6}$ The Wald statistic is the square of the slope $\beta$ divided by the standard error, and has a chi-square distribution with $\mathrm{df}=1$ (Agresti and Finlay 1997).
} 
church group membership did contribute significantly to the equation. Wealth therefore did not appear to affect participation in dairy-goat groups. Although the poorer farmers were originally targeted to be members of the groups, there was no significant difference between dairy-goat group members and non-members with regard to wealth levels.

For 84 percent of the DGGs, paying a fee was a requirement to join. This shows that farmers must have at least some amount of cash to join dairy-goat groups, and could have been a factor preventing the very poor in the community from joining groups. Poor people (as opposed to the very poor) appeared to participate in dairy-goat groups (see Table 5).

Dairy-goat group leadership was examined to see whether gender, age level, or wealth had an effect on participation in group leadership. This could also have an effect on group membership in general, because people may feel more comfortable in groups that are comprised of leaders of their same gender, age set, or wealth level. Table 9 shows the group leaders and their gender, age, and wealth level.

It is apparent that there were more men chairpersons (70 percent). Although the groups were 59 percent women, men were over-represented in the chairperson position. The secretary position was more balanced between men and women. However, the treasurer position was skewed toward women (76 percent). 
Table 9--Frequencies for group leaders' gender, age and wealth level $\left(n=138^{\mathbf{a}}\right)$

\begin{tabular}{llllll}
\hline Variable & Sublevel & Chairperson & Secretary & Treasurer & Total \\
\hline Gender & Men & $32(70)$ & $26(57)$ & $11(24)$ & $69(50)$ \\
& Women & $14(30)$ & $20(43)$ & $35(76)$ & $69(50)$ \\
\hline Age & $<30$ & $4(9)$ & $2(4)$ & $4(9)$ & $10(7)$ \\
& $31-49$ & $18(39)$ & $41(89)$ & $30(65)$ & $89(64)$ \\
& $>50$ & $24(52)$ & $2(4)$ & $11(24)$ & $37(27)$ \\
\hline \multirow{2}{*}{ Wealth } & Below avg. & $9(20)$ & $10(22)$ & $4(9)$ & $23(17)$ \\
& Average & $32(70)$ & $32(70)$ & $29(63)$ & $93(67)$ \\
& Above avg. & $5(11)$ & $4(9)$ & $13(28)$ & $22(16)$ \\
\hline
\end{tabular}

a 3 leaders in each of the 46 groups

Note: Figures in ( ) are percentages.

\section{Information Sources and Diffusion by Men and Women Farmers}

Although no difference was seen between the number of meetings attended by men and women farmers regarding agricultural information (Table 10), there did seem to be some gender differences regarding the types of information sources seen as important (Table 11).

Government extension was the most important source of information for both men and women farmers. The top three sources of agricultural information for men and women farmers, whether or not they were in either type of dairy-goat group, always included extension, other farmers, and groups. Indigenous knowledge (knowledge passed on from parents or gained through the local community) appeared to be somewhat more important for women. Higher percentages of women cited indigenous knowledge as one of their top three information sources.

Table 10--Frequency of meeting attendance by gender $(n=88)$

\begin{tabular}{|c|c|c|c|c|}
\hline \multirow{2}{*}{$\begin{array}{l}\text { Number of meetings } \\
\text { attended }^{\text {a }}\end{array}$} & \multicolumn{2}{|l|}{ Women $(n=46)$} & \multicolumn{2}{|c|}{$\operatorname{Men}(n=42)$} \\
\hline & $f$ & $\%$ & $f$ & $\%$ \\
\hline Zero & 28 & 61 & 22 & 52 \\
\hline One & 12 & 26 & 12 & 29 \\
\hline Two & 3 & 7 & 4 & 10 \\
\hline Three or more & 3 & 7 & 4 & 10 \\
\hline Total & 46 & 100 & 42 & 100 \\
\hline
\end{tabular}

${ }^{a}$ in the previous month, where agricultural information is available

Note: $\gamma=.164 ; p<.374$ 
There were significant differences by gender with regard to frequency of dissemination (Table 12). Many more women farmers had not diffused information or technologies to other farmers in the past five years. More men, on the other hand, had disseminated information/technologies to "some" (6-10) farmers, while both groups had diffused to a "few" (1-5). There was no significant difference between men and women farmers with regard to whom exactly they diffused information to (Table 13).

Table 11--Source of information/technologies to all respondents by gender $(n=88)$

\begin{tabular}{|c|c|c|c|c|c|}
\hline & & \multicolumn{2}{|c|}{ Women $(n=46)$} & \multicolumn{2}{|c|}{$\operatorname{Men}(n=42)$} \\
\hline & & $f$ & $\%$ & $f$ & $\%$ \\
\hline \multirow[t]{9}{*}{ Source1 } & Extension & 17 & 37 & 19 & 45 \\
\hline & Farmers & 1 & 2 & 2 & 5 \\
\hline & Groups & 2 & 4 & 2 & 5 \\
\hline & FARM & 3 & 7 & 5 & 12 \\
\hline & Radio & 1 & 2 & 0 & 0 \\
\hline & Church & 7 & 15 & 2 & 5 \\
\hline & Baraza $^{\mathrm{a}}$ & 1 & 2 & 5 & 12 \\
\hline & Other & 8 & 17 & 6 & 14 \\
\hline & $\mathrm{IK}^{\mathrm{b}}$ & 6 & 13 & 1 & 2 \\
\hline \multirow[t]{9}{*}{ Source2 } & Extension & 2 & 4 & 8 & 20 \\
\hline & Farmers & 13 & 30 & 4 & 10 \\
\hline & Groups & 2 & 4 & 7 & 17 \\
\hline & FARM & 3 & 7 & 2 & 5 \\
\hline & Radio & 1 & 2 & 1 & 3 \\
\hline & Church & 9 & 21 & 5 & 12 \\
\hline & Baraza & 3 & 7 & 2 & 5 \\
\hline & Other & 5 & 11 & 8 & 20 \\
\hline & $\mathrm{IK}$ & 6 & 14 & 3 & 8 \\
\hline \multirow[t]{9}{*}{ Source3 } & Extension & 4 & 11 & 2 & 6 \\
\hline & Farmers & 3 & 9 & 6 & 17 \\
\hline & Groups & 8 & 23 & 2 & 5 \\
\hline & FARM & 2 & 6 & 2 & 5 \\
\hline & Radio & 1 & 3 & 2 & 6 \\
\hline & Church & 4 & 11 & 4 & 11 \\
\hline & Baraza & 5 & 14 & 2 & 6 \\
\hline & Other & 3 & 9 & 12 & 33 \\
\hline & $\mathrm{IK}$ & 5 & 14 & 4 & 11 \\
\hline
\end{tabular}

${ }^{a}$ Local government administration (sub-location and location level)

${ }^{\mathrm{b}}$ Indigenous knowledge of agriculture and technology 
Table 12--Frequency of dissemination to other farmers by respondents in all groups by gender

\begin{tabular}{lllll}
\hline & \multicolumn{2}{l}{ Women $(\mathrm{n}=46)$} & \multicolumn{2}{l}{ Men $(\mathrm{n}=42)$} \\
& $f$ & $\%$ & $f$ & $\%$ \\
\hline None & 18 & 39 & 7 & 17 \\
Few (1-5 farmers) & 5 & 11 & 8 & 19 \\
Some (6-10 farmers) & 13 & 28 & 23 & 55 \\
Total & 36 & 78 & 38 & 91 \\
Missing values & 10 & 22 & 4 & 10 \\
\hline Total & 46 & 100 & 42 & 100 \\
\hline
\end{tabular}

Note: $\gamma=.491 ; p<0.006$ (Gamma is a measure of association for ordinal variables).

Table 13--Recipients of information and technologies from respondents in all groups by gender

\begin{tabular}{lllll}
\hline & \multicolumn{2}{l}{ Women $(\mathrm{n}=46)$} & \multicolumn{2}{c}{ Men $(\mathrm{n}=42)$} \\
& $f$ & $\%$ & $f$ & $\%$ \\
\hline Neighbor & 21 & 46 & 21 & 50 \\
Friend & 5 & 11 & 4 & 10 \\
Relative & 2 & 4 & 2 & 5 \\
Farmer from another location & 8 & 17 & 6 & 14 \\
Other & 6 & 13 & 4 & 10 \\
\hline
\end{tabular}

Note: $X^{2}=(4, \mathrm{n}=88) .482 ; p<.98$

\section{DISCUSSION}

Gender played a role in the types of community groups that men and women participated in, how they accessed information, and the volume of dissemination to other farmers. Wealth, however, did not seem to play such a large role in affecting group membership, although various factors related to wealth (e.g., land size, remittances) did appear to affect group participation.

Household composition was one of these factors, related to both wealth and gender, that seemed to play a role in membership in community groups. This is a complex and fluctuating variable that is difficult to analyze. How household composition affects time and wealth goes 
beyond the scope of this paper, but these results seem to point to some type of effect that would be useful for future studies to examine.

Similarly to other studies, this study found women participating in different types of groups than men, although the reasons given for participation in groups were not very different between men and women for this study.

Cultural factors likely affected the participation of women in groups. In Meru culture, men own many assets such as land and animals, while women usually do not. With the dairygoat groups, the work added on by caring for the goats might be too much on top of the household duties that a woman already has. Often, if just one spouse joined a dairy-goat group, the other might get involved as well, although not necessarily officially. Since women often care for people and animals around the household, the chore of caring for goats often falls on them, even if it is their husbands who are in the groups.

With regard to leadership among all of the DGGs, it is apparent that there were more men chairpersons (70 percent), who also tended to be older. Although the DGGs groups were 59 percent women, men were over-represented in the chairperson position. This is likely due to the traditional role of men in the Meru society, and the fact that men might be able to more strongly represent the group before the chief, in government offices, and so forth. This may also be part of the reason why men are sometimes allowed to join women's groups in Kenya. ${ }^{7}$

The secretary position of the DGGs was more balanced between men and women. However, the treasurer position was skewed toward women ( 76 percent). Stakeholders felt that

\footnotetext{
${ }^{7}$ In general, not necessarily a result of this particular study. Table 2, showing individual respondents' participation in groups, shows what types of groups individual respondents (DGG members and their neighbors) were in, rather than a complete depiction of women's groups in Meru and who participated in them.
} 
this was because men were less trusted with money than women and were not transparent with accounts. Also, there was a cultural issue at work; in Kenya, men tend to be owners while women are managers. Women may therefore have been viewed as more likely to properly manage the funds - and not end up "owning" them.

With regard to wealth, many of the community self-help groups (as opposed to groups like cooperatives) in Kenya are formed for the resource-poor, to bring about some benefit or "uplifting," according to respondents. Therefore the "poor" are the ones participating in many of the groups. One informant said, "The poor are mostly in groups." They naturally come together because they have needs. When the DGG project began working in Meru, they held discussions with community members about who were the "poorest of the poor." They categorized such people as having small farms and no cattle. They also had a lack of regular income and proper shelter and could not educate their children.

Although the dairy-goat project specifically targeted poor people, it appeared that sometimes the very poor could not join groups. Lack of capital was the main reason. According to informants, they were the people lagging behind — they had nothing. They may not have had the resources to join groups, or were afraid that they would be exploited if they joined a group. One of the farmers interviewed who was not in any group said that it was due to lack of money. However, only two percent of farmers interviewed said they were not in any group at all.

It was noted during the stakeholder validation meeting that many of the treasurers appeared to be in a higher wealth category than the other leaders ( 28 percent of treasurers were above average, while 11 percent of chairpersons and 9 percent of secretaries were above average). According to the stakeholders present at the meeting, having treasurers who were wealthier perhaps provided a means for the group to get their money back if the treasurer 
misused it. In other words, the relative wealth of the treasurer may have provided a sort of collateral; if the need to take legal action against the treasurer arose, group members would have a better chance of getting their money back. Managing finances also requires a certain level of education, which is likely to put one in an advantaged position in terms of income/wealth. Disputes are usually sorted out within the group regulations and rarely reach the formal legal government structures, except in the case of cooperatives.

Regarding information sources and dissemination, there was not much difference between men and women farmers as to numbers of meeting attended where agricultural information is available, nor to the types of persons to whom they disseminated information (e.g., neighbors, friends, relatives, or farmers from another area). However, there were gender differences in the importance of information sources for men and women, and similarities in that both groups usually listed extension, other farmers, and groups as the most important sources of information in general. There were also differences in terms of how much women and men disseminated.

The top three sources of agricultural information for men and women farmers, whether or not they were in dairy-goat groups, always included extension, other farmers, and groups. Extension was the primary source for the majority of farmers interviewed. This is interesting in light of the constraints that extension faces in Kenya today, and the criticism of government extension as being unavailable. However, this probably illustrates an effective partnership between the public and private sector, where the NGO had the funds and the Ministry had the personnel, and the project married the two effectively. Perhaps this can be a lesson to policy makers, that both men and women farmers tend to find access to government extension services through this type of partnership. 
The fact that women tend to rate churches and indigenous knowledge as more important sources of knowledge than men makes it clear that development agencies must target specific mechanisms for dissemination to reach different types of farmers.

Men appeared to be disseminating to greater numbers of people, but men and women disseminated to similar types of people. This is similar to Katungi et al.'s (2006) study, which found that there was no difference in men and women as far as "weak ties"- the links to people outside their sub-county.

\section{CONCLUSIONS}

Gender appeared to play a role in participation in community groups and in the DGG leadership positions in Meru. Women tended to participate more in merry-go-rounds, church groups, and women's groups, while men participated more in clan and water groups. However, their reasons for joining groups were not so different. Wealth did not appear to play a significant role in group participation, although this could be influenced by the project's targeting the perceived "poorer" farmers. Some effects of household composition (related to both wealth and gender) should be teased out in future studies.

There were both differences and similarities between men and women farmers as to sources of information, and the volume of dissemination of the information. Extension was the most important source for both groups. Other farmers and farmer groups were also important for both men and women farmers. Women tended to rank indigenous knowledge and the church higher than men in terms of providing agricultural information. Although men tended to 
disseminate to greater numbers of people than women, both were disseminating to similar types of people (neighbors, friends, relatives, and farmers from outside their local area).

The dairy-goat project also shows that if targeted, women and lower wealth levels can and will participate in and benefit from development programs. Although targeting the poor, there was no significant difference between member and non-member farmers of dairy-goat groups with regard to wealth level. However, it must be noted that this study was not longitudinal and so comparisons of wealth over time were not possible. It is possible that the wealth levels of the farmers changed as a result of the project.

These findings indicate that different groups (men, women, the poor) can be targeted through particular institutions, including community groups. Mechanisms should also be implemented that include the poor and women more in market- and income-related types of groups. But these will have to take into account the fact that all farmers cannot be uniformly included in one type of group, due to differences in culture, resources, and personal preferences.

Given that the Kenyan extension strategy is to work through groups, this study should add to this impetus with evidence that groups can be useful vehicles for linking farmers, especially women, to extension and other sources of information. However, it may be best to work through traditional types of groups or institutions where women and the poor may feel more comfortable participating, while at the same time modifying them toward more income- or market-related goals so as to lead toward Kenya's development objectives and the Millennium Development Goals. This dairy-goat project, a meld of the public, private, civil society, and traditional institutions may be an interesting model for policymakers in this regard. 


\section{REFERENCES}

Agresti, A. and B. Finlay. 1997. Statistical methods for the social sciences $\left(3^{\text {rd }}\right.$ ed.). Upper Saddle River, NJ: Prentice Hall.

Agrawal, A., G. Yadama, R. Andrade, and A. Bhattacharya. 2006. Decentralization and environmental conservation: Gender effects from participation in joint forest management. CAPRI Working Paper 53. Washington, DC: CGIAR Systemwide Program on Collective Action and Property Rights.

Davis, K.E. 2004. Technology Dissemination among small-scale farmers in Meru Central District of Kenya: Impact of group participation. Ph.D. dissertation, University of Florida, Gainesville.

Davis, K. E., S. Franzel, P. Hildebrand, T. Irani and N. Place. 2004. Extending Technologies Among Small-Scale Farmers in Meru, Kenya. The Journal of Agricultural Education and Extension 10: 53-62.

FARM-Africa. 2002. Meru dairy-goat and animal health care phase II April 1999-March 2002 Project Review. Nairobi: FARM-Africa.

George, D. and P. Mallery. 2001. SPSS for windows step by step: A simple guide and reference. 10.0 update $\left(3^{\text {rd }}\right.$ ed.). Needham Heights, MA: Allyn \& Bacon.

Godquin, M. and A. R. Quisumbing. 2006. Groups, networks, and social capital in rural Philippine communities. A paper presented at the International Research Workshop on Gender and Collective Action, October 17-21, 2005, Chiang Mai, Thailand.

Kariuki, G. and F. Place. 2005. Initiatives for rural development through collective action: The case of household participation in group activities in the highlands of central Kenya. CAPRI Working Paper 43. Washington, DC: CGIAR Systemwide Program on Collective Action and Property Rights.

Katungi, E., S. Emeades, and M. Smale. 2006. Gender, social capital and information exchange in rural Uganda. CAPRi Working Paper 59. Washington, DC: CGIAR Systemwide Program on Collective Action and Property Rights.

Meru Central District Development Plan. 2002. Effective management for sustainable economic growth and poverty reduction, 2002-2008. Nairobi, Kenya: Republic of Kenya Ministry of Finance and Planning. 
Place, F., G. Kariuki, J. Wangila, P. Kristjanson, A. Makauki and J. Ndubi 2002. Assessing the factors underlying differences in group performance: Methodological issues and empirical findings from the highlands of Central Kenya. CAPRI Working Paper 25. Washington, DC: CGIAR Systemwide Program on Collective Action and Property Rights.

Stringfellow, R., Coulter, J., Lucey, T., McKone, C. \& Hussain, A. 1997. Improving the access of smallholders to agricultural services in sub-Saharan Africa: Farmer cooperation and the role of the donor community. Natural Resource Perspectives 20. Overseas Development Institute.

Teel, W. 1985. A pocket directory of trees and seeds in Kenya. Nairobi, Kenya: KENGO.

Were, G. S. and S.Wandibba, ed. 1988. Meru district socio-cultural profile. Nairobi, Kenya: Government of Kenya. 


\section{List of CAPRi Working Papers}

01 Property Rights, Collective Action and Technologies for Natural Resource Management: A Conceptual Framework, by Anna Knox, Ruth Meinzen-Dick, and Peter Hazell, October 1998.

02 Assessing the Relationships between Property Rights and Technology Adoption in Smallholder Agriculture: A Review of Issues and Empirical Methods, by Frank Place and Brent Swallow, April 2000.

03 Impact of Land Tenure and Socioeconomic Factors on Mountain Terrace Maintenance in Yemen, by A. Aw-Hassan, M. Alsanabani and A. Bamatraf, July 2000.

04 Land Tenurial Systems and the Adoption of a Mucuna Planted Fallow in the Derived Savannas of West Africa, by Victor M. Manyong and Victorin A. Houndékon, July 2000 .

05 Collective Action in Space: Assessing How Collective Action Varies Across an African Landscape, by Brent M. Swallow, Justine Wangila, Woudyalew Mulatu, Onyango Okello, and Nancy McCarthy, July 2000.

06 Land Tenure and the Adoption of Agricultural Technology in Haiti, by Glenn R. Smucker, T. Anderson White, and Michael Bannister, October 2000.

07 Collective Action in Ant Control, by Helle Munk Ravnborg, Ana Milena de la Cruz, María Del Pilar Guerrero, and Olaf Westermann, October 2000.

08 CAPRi Technical Workshop on Watershed Management Institutions: A Summary Paper, by Anna Knox and Subodh Gupta, October 2000.

09 The Role of Tenure in the Management of Trees at the Community Level: Theoretical and Empirical Analyses from Uganda and Malawi, by Frank Place and Keijiro Otsuka November 2000.

10 Collective Action and the Intensification of Cattle-Feeding Techniques a Village Case Study in Kenya's Coast Province, by Kimberly Swallow, November 2000.

11 Collective Action, Property Rights, and Devolution of Natural Resource Management: Exchange of Knowledge and Implications for Policy, by Anna Knox and Ruth MeinzenDick, January 2001. 
12 Land Dispute Resolution in Mozambique: Evidence and Institutions of Agroforestry Technology Adoption, by John Unruh, January 2001.

13 Between Market Failure, Policy Failure, and "Community Failure": Property Rights, Crop-Livestock Conflicts and the Adoption of Sustainable Land Use Practices in the Dry Area of Sri Lanka, by Regina Birner and Hasantha Gunaweera, March 2001.

14 Land Inheritance and Schooling in Matrilineal Societies: Evidence from Sumatra, by Agnes Quisumbing and Keijuro Otsuka, May 2001.

15 Tribes, State, and Technology Adoption in Arid Land Management, Syria, by Rae, J, Arab, G., Nordblom, T., Jani, K., and Gintzburger, G., June 2001.

16 The Effects of Scales, Flows, and Filters on Property Rights and Collective Action in Watershed Management, by Brent M. Swallow, Dennis P. Garrity, and Meine van Noordwijk, July 2001.

17 Evaluating Watershed Management Projects, by John Kerr and Kimberly Chung, August 2001.

18 Rethinking Rehabilitation: Socio-Ecology of Tanks and Water Harvesting in Rajasthan, North-West India, by Tushaar Shah and K.V.Raju, September 2001.

19 User Participation in Watershed Management and Research, by Nancy Johnson, Helle Munk Ravnborg, Olaf Westermann, and Kirsten Probst, September 2001.

20 Collective Action for Water Harvesting Irrigation in the Lerman-Chapala Basin, Mexico, by Christopher A. Scott and Paul Silva-Ochoa, October 2001.

21 Land Redistribution, Tenure Insecurity, and Intensity of Production: A Study of Farm Households in Southern Ethiopia, by Stein Holden and Hailu Yohannes, October 2001.

22 Legal Pluralism and Dynamic Property Rights, by Ruth Meinzen-Dick and Rajendra Pradhan, January 2002.

23 International Conference on Policy and Institutional Options for the Management of Rangelands in Dry Areas, by Tidiane Ngaido, Nancy McCarthy, and Monica Di Gregorio, January 2002.

24 Climatic Variablity and Cooperation in Rangeland Management: A Case Study From Niger, by Nancy McCarthy and Jean-Paul Vanderlinden, September 2002. 
25 Assessing the Factors Underlying the Differences in Group Performance:

Methodological Issues and Empirical Findings from the Highlands of Central Kenya, by Frank Place, Gatarwa Kariuki, Justine Wangila, Patti Kristjanson, Adolf Makauki, and Jessica Ndubi, November 2002.

26 The Importance of Social Capital in Colombian Rural Agro-Enterprises, by Nancy Johnson, Ruth Suarez, and Mark Lundy, November 2002.

27 Cooperation, Collective Action and Natural Resources Management in Burkina Faso: A Methodological Note, by Nancy McCarthy, Céline Dutilly-Diané, and Boureima Drabo, December 2002.

28 Understanding, Measuring and Utilizing Social Capital: Clarifying Concepts and Presenting a Field Application from India, by Anirudh Krishna, January 2003.

29 In Pursuit Of Comparable Concepts and Data, about Collective Action, by Amy Poteete And Elinor Ostrom, March 2003.

30 Methods of Consensus Building for Community Based Fisheries Management in Bangladesh and the Mekong Delta, by Parvin Sultana and Paul Thompson, May 2003.

31 Formal and Informal Systems in Support of Farmer Management of Agrobiodiversity: Some Policy Challenges to Consolidate Lessons Learned, by Marie Byström, March 2004.

32 What Do People Bring Into the Game: Experiments in the Field About Cooperation in the Commons, by Juan-Camilo Cárdenas and Elinor Ostrom, June 2004.

33 Methods for Studying Collective Action in Rural Development, by Ruth Meinzen-Dick, Monica Di Gregorio, and Nancy McCarthy, July 2004.

34 The Relationship between Collective Action and Intensification of Livestock

Production: The Case of Northeastern Burkina Faso, by Nancy McCarthy, August 2004.

35 The Transformation of Property Rights in Kenya's Maasailand: Triggers and Motivations by Esther Mwangi, January 2005.

36 Farmers' Rights and Protection of Traditional Agricultural Knowledge, by Stephen B. Brush, January 2005.

37 Between Conservationism, Eco-Populism and Developmentalism - Discourses in Biodiversity Policy in Thailand and Indonesia, by Heidi Wittmer and Regina Birner, January 2005. 
38 Collective Action for the Conservation of On-Farm Genetic Diversity in a Center of Crop Diversity: An Assessment of the Role of Traditional Farmers' Networks, by Lone B. Badstue, Mauricio R. Bellon, Julien Berthaud, Alejandro Ramírez, Dagoberto Flores, Xóchitl Juárez, and Fabiola Ramírez, May 2005.

39 Institutional Innovations Towards Gender Equity in Agrobiodiversity Management: Collective Action in Kerala, South India,, by Martina Aruna Padmanabhan, June 2005.

40 The Voracious Appetites of Public versus Private Property: A View of Intellectual Property and Biodiversity from Legal Pluralism, by Melanie G. Wiber, July 2005.

41 Who Knows, Who Cares? Determinants of Enactment, Awareness and Compliance with Community Natural Resource Management Bylaws in Uganda, by Ephraim Nkonya, John Pender, Edward Kato, Samuel Mugarura, and James Muwonge, August 2005.

42 Localizing Demand and Supply of Environmental Services: Interactions with Property Rights, Collective Action and the Welfare of the Poor, by Brent Swallow, Ruth Meinzen-Dick, and Meine von Noordjwik, September 2005.

43 Initiatives for Rural Development through Collective Action: The Case of Household Participation in Group Activities in the Highlands of Central Kenya, By Gatarwa Kariuki and Frank Place, September 2005.

44 Are There Customary Rights to Plants? An Inquiry among the Baganda (Uganda), with Special Attention to Gender, by Patricia L. Howard and Gorettie Nabanoga, October 2005.

45 On Protecting Farmers' New Varieties: New Approaches to Rights on Collective Innovations in Plant Genetic Resources by Rene Salazar, Niels P. Louwaars, and Bert Visser, January 2006.

46 Subdividing the Commons: The Politics of Property Rights Transformation in Kenya's Maasailand, by Esther Mwangi, January 2006.

47 Biting the Bullet: How to Secure Access to Drylands Resources for Multiple Users, by Esther Mwangi and Stephan Dohrn, January 2006.

48 Property Rights and the Management of Animal Genetic Resources, by Simon Anderson and Roberta Centonze, February 2006. 
49 From the Conservation of Genetic Diversity to the Promotion of Quality Foodstuff: Can the French Model of 'Appellation d'Origine Contrôlée' be Exported? by Valérie Boisvert, April 2006.

50 Facilitating Collective Action and Enhancing Local Knowledge: A Herbal Medicine Case Study in Talaandig Communities, Philippines, by Herlina Hartanto and Cecil Valmores, April 2006.

51 Water, Women and Local Social Organization in the Western Kenya Highlands, by Elizabeth Were, Brent Swallow, and Jessica Roy, July 2006.

52 The Many Meanings of Collective Action: Lessons on Enhancing Gender Inclusion and Equity in Watershed Management, by Laura German, Hailemichael Taye, Sarah Charamila, Tesema Tolera, and Joseph Tanui, July 2006.

53 Decentralization and Environmental Conservation: Gender Effects from Participation in Joint Forest Management, by Arun Agrawal, Gautam Yadama, Raul Andrade, and Ajoy Bhattacharya, July 2006.

54 Improving the Effectiveness of Collective Action: Sharing Experiences from Community Forestry in Nepal, by Krishna P. Achyara and Popular Gentle, July 2006.

55 Groups, Networks, and Social Capital in the Philippine Communities, by Marie Godquin and Agnes R. Quisumbing, October 2006.

56 Collective Action in Plant Genetic Resources Management: Gendered Rules of Reputation, Trust and Reciprocity in Kerala, India, by Martina Aruna Padmanabhan, October 2006.

57 Gender and Local Floodplain Management Institutions--A case study from Bangladesh, by Parvin Sultana and Paul Thompson, October 2006.

58 Gender Differences in Mobilization for Collective Action: Case Studies of Villages in Northern Nigeria, by Saratu Abdulwahid, October 2006.

59 Gender, Social Capital and Information Exchange in Rural Uganda, by Enid Katungi, Svetlana Edmeades, and Melinda Smale, October 2006.

60 Rural Institutions and Producer Organizations in Imperfect Markets: Experiences from Producer Marketing Groups in Semi-Arid Eastern Kenya, by Bekele Shiferaw, Gideon Obare and Geoffrey Muricho, November 2006. 
61 Women's Collective Action and Sustainable Water Management: Case of SEWA's Water Campaign in Gujarat, India, by Smita Mishra Panda, October 2006.

62 Could Payments for Environmental Services Improve Rangeland Management inCentral Asia, West Asia and North Africa? by Celine Dutilly-Diane, Nancy McCarthy, Francis Turkelboom, Adriana Bruggeman, James Tiedemann, Kenneth Street and Gianluca Serra, January 2007.

63 Empowerment through Technology: Gender Dimensions of Social Capital Build-Up in Maharashtra, India, by Ravula Padmaja and Cynthia Bantilan, February 2007.

64 Gender and Collective Action: A Conceptual Framework for Analysis, by Lauren Pandolfelli, Ruth Meinzen-Dick, and Stephan Dohrn, May 2007. 